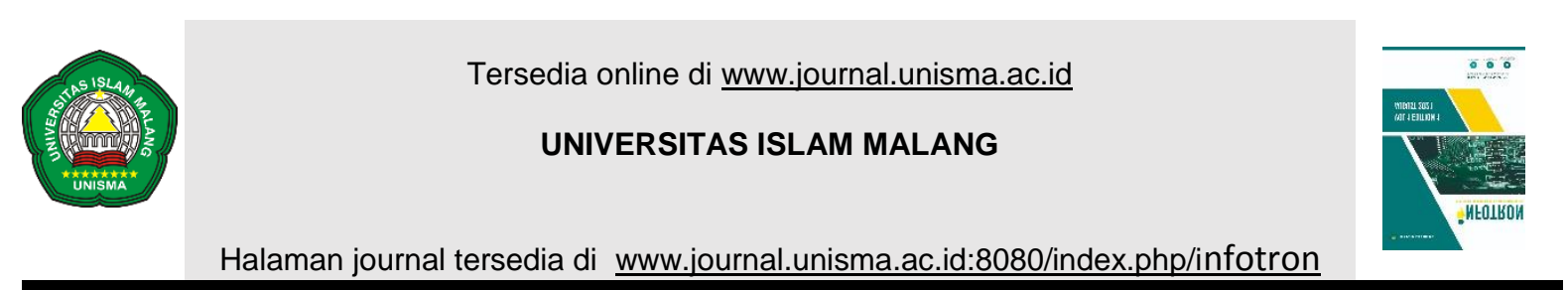

\title{
RANCANG BANGUN APLIKASI MANAJEMEN ORGANISASI MAHASISWA DENGAN METODE PROTOTYPING ( FAKULTAS TEKNIK UNIVERSITAS ISLAM MALANG)
}

\author{
Alvin Setiawan a, Bambang Minto b, Fawaidul Badri c \\ a Teknik Elektro, Universitas Islam Malang, Kota Malang, Indonesia \\ ${ }^{b}$ Teknik Elektro, Universitas Islam Malang, Kota Malang, Indonesia \\ c Teknik Elektro, Universitas Islam Malang, Kota Malang, Indonesia \\ email:a alvinsetiawan135@gmail.com, ${ }^{b}$ bambangminto@unisma.ac.id, cfawaidulbadri@unisma.ac.id
}

INFORMASI

ARTIKEL

Sejarah artikel:

Received 6 Mei 2021

Accepted 3 Juni 2021

Kata kunci: [ Manajemen Organisasi], [Android], [Software]

\begin{abstract}
Manajemen organisasi mahasiswa sampai saat ini kurang efektif karena belum adanya suatu sistem informasi untuk manajemen organisasi mahasiswa yang terintegrasi secara menyeluruh oleh bagian kemahasiswaan yang ada di Universitas Islam Malang. Permasalahan dalam setiap organisasi untuk menunjang sistem informasi dan manajemen dari setiap organisasi mahasiswa seperti memanajemen departemen setiap organisasi seprti sekertaris, bendahara, sumberdaya mahasiswa, kerumahtanggaan, media dan informasi, di Universitas Islam Malang. Untuk menangani hal tersebut, diperlukan aplikasi manajemen organisasi, sehingga peneliti membuat rancangan program aplikasi manajemen organisasi berbasis android yang mudah dipakai oleh pengguna smartphone. Dalam penelitian ini menggunakan metode prototyping karena untuk memperkecil resiko rekayasa ulang proses bisnis. Prototype dapat memberikan ide bagi pembuat dan pemakai potensial tentang cara sistem berfungsi dalam bentuk lengkapnya. Dalam tahap penelitian ini yaitu dari penggalian kebutuhan, desain aplikasi, implementasi prototype, evaluasi aplikasi, desain final, implementasi hasil dan pengujian. Dalam tujuan penelitian ini yaitu membangun aplikasi manajemen organisasi untuk dapat mengetahui konsep dan pengujian aplikasi manajemen organisasi mahasiswa. Hasil dalam penelitian ini medapatkan pengujian di kategorikan sangat layak dengan presentase pengujian dengan pecobaan ke pengguna organisasi responden 10 anggota organisasi mendapatkan skor 210 sehingga menghasilkan dari perhitungan mendapatkan presentase kelayakan $84 \%$ dan pengujian fitur mendapatkan skor 700 sehingga menghasilkan presentase kelayakan $100 \%$.
\end{abstract}

() 2021 INFOTRON: Jurnal IImiah Teknik Informatika, Elektronika dan Kontrol (Scientific Journal of Informatics, Electronics and Control Engineering). Copyrights. All rights reserved..

\section{Pendahuluan}

Manajemen organisasi mahasiswa sampai saat ini kurang efektif karena belum adanya suatu sistem informasi tentang manajemen organisasi mahasiswa yang terintegrasi secara menyeluruh oleh bagian kemahasiswaan yang ada di Universitas Islam Malang. Sistem informasi yang ada pada saat ini hanya menjalankan manajemen organisasi secara manual, sehingga untuk menjalankan suatu manajemen organisasi mahasiswa terhambat untuk menjalankan suatu manjemen organisasi yang ada di Universitas Islam Malang.

Banyaknya kegiatan kemahasiswaan tersebut memerlukan dokumentasi kegiatan dari berbagai macam kegiatan kemahasiwaaan serta jadwal kegiatan pada kemahasiswaan. Permasahan dalam setiap organisasi untuk menunjang manajemen dari setiap organisasi itu sendiri seperti 
memanajemen pelaksanaan dari program kerja, Birokrasi kampus dan pengenalan organisasi, untuk mempermudah menangani hal seperti itu memerlukan aplikasi manajemen organisasi.

Untuk memenuhi kebutuhan tersebut peneliti membuat rancangan program aplikasi manajemen organisasi berbasis android yang dibangun dengan Android Studio. Aplikasi berbasis android dapat mudah di pakai oleh pengguna smartphone. Software ini di buat dengan Bahasa pemograman Java dan XML.Pemograman Java di gunakan mengingat memiliki fleksibilitas yang tinggi sebagai multiplatform yang dapat di jalankan di beberapa platform sistem operasi computer dan dengan dukungan XML yang memiliki sedikit aturan, mudah di kembangkan. Dalam bangun software ini mengunggunakan data base platform firebase database ini melanjutkan keberhasilan Realtime database dengan model data baru yang lebih intuitif. Cloud Firestore juga memiliki fitur kueri yang lebih lengkap dan lebih cepat

\section{Penelitian Terdahulu}

Ana Juita Oktasari, Denny Kurniadi (2020) Perancangan Sistem Informasi Manajemen Kegiatan Mahasiswa Berbasis WEB. Dalam perancangan sistem informasi ini menggunakan metode waterfall dan metode Object Oriented Programming (OOP). Sistem ini juga menggunakan teknik Model View Controller (MVC). Sistem ini dirancang menggunakan Framework Yii2 dengan bahasa pemrograman Hypertext Preprocessor (PHP) dan Database Management System (DBMS) MySQL. Perancangan sistem informasi manajemen kegiatan mahasiswa menghasilkan sistem yang dapat mempermudah unit kegiatan mahasiswa di Universitas Negeri Padang dalam mengajukan proposal dan laporan kegiatan serta membantu KaSubag Kemahasiswaan dalam mengelola informasi mengenai kegiatan mahasiswa. [3]

Elian Danu dan Ria Risti Astanti (2018) Rancang Bangun Aplikasi Sistem Informasi Pada Badan Eksekutif Mahasiswa STMIK Pontianak. Bentuk penelitian yang digunakan adalah Research and Development (R\&D). Teknik pengumpulan dengan observasi kasus langsung maupun melalui internet dan media elektronik. Perangkat alat analisis yang digunakan; Use Case Diagram, Activity Diagram, Sequence Diagram dan Class Diagram.Teknik pengujian menggunakan black box. Hasil penelitian ini dapat membantu meningkatkan kinerja pada bidang kemahasiswaan dan juga dapat digunakan sebagai media promosi kampus agar dapat lebih dikenal oleh masyarakat lewat sebuah system informasi tersebut.[4]

Sri Lis Apriliani, Shinta Esabella, M. Julkarnain (2020) Rancang Bangun Aplikasi Monitoring Unit Kegiatan Mahasiswa (UKM) Universitas Teknologi Sumbawa Berbasis WEB. Metode penelitian yang digunakan yaitu metode lapangan yang bersifat deskriptif dan metode pengumpulaln data yang digunakan dalam penelitian ini yaitu metode observasi, wawancara, dan studi pustaka serta menggunakan metode Plan, Do, Check, Act (PDCA) sebagai metode pengembangan perangkat lunak. Aplikasi UKM di Universitas Teknologi Sumbawa Berbasis WEB ini dibangun menggunakan bahasa pemrograman Hypertext Prepocessor (PHP) dan basis data MySQL sebagai Database Management System (DBMS). Dalam Aplikasi Monitoring Unit Kegiatan Mahasiswa (UKM) Universitas Teknologi Sumbawa Berbasis WEB setiap ketua UKM yang memiliki wewenang untuk menginput data kegiatan, prestasi yang dicapai serta nama anggota yang UKM yang dilaporkan atau diinput setiap semesternya.[5]

\section{Metode}

1. Tempat Penelitian

Penelitian akan dilaksanakan di kampus Universitas Islam Malang dimana produk tersebut dibuat untuk kampus Universitas Islam Malang.

2. Jadwal Penelitian

Penelitian ini dilaksanakan pada bulan Maret - Juni 2021.

3. Tahap perancangan

Dalam tahap pendekatan pengembangan perangkat lunak metode yang di gunakan dengan metode prototyping. Dalam perancangan aplikasi MANAJEMEN ORGANISASI, Secara menyeluruh 
terdiri dari beberapa tahapan yang harus dilalui agar aplikasi yang akan dibuat dapat diselesaikan dengan baik.

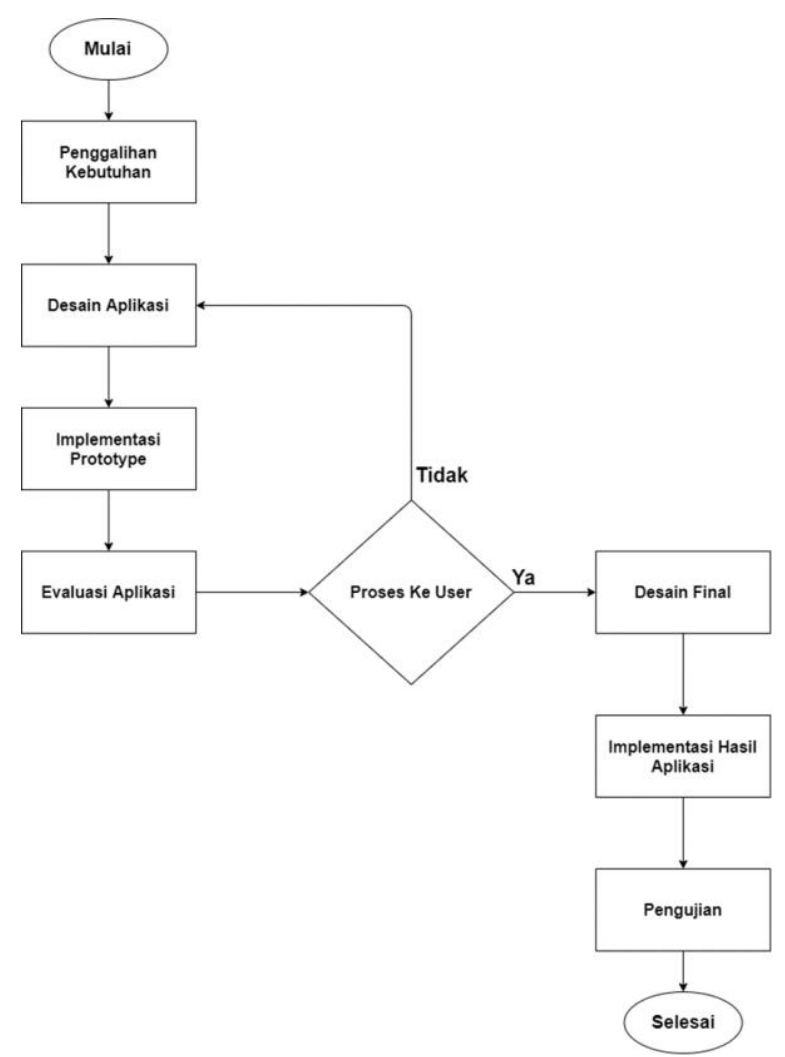

Gambar 2.1 Flowchart Kerangka Pikir

(Sumber : Pengujian)

Berdasarkan flowchart di atas, maka dapat diuraikan tahapan-tahapan sebagai berikut.

1. Penggalihan Kebutuhan

a. Kebutuhan Fungsional

- Manajemen Departemen Sumber Daya Mahasiswa (SDM)

- Manajemen Departemen Sekretaris

- Manajemen Bendahara

- Manajemen Kerumahtanggaan (KRT)

- Manajemen Media dan Informasi (MEDINFO)

b. Kebutuhan Non-Fungsional

Tabel 2.1 Perangkat yang dibutuhkan

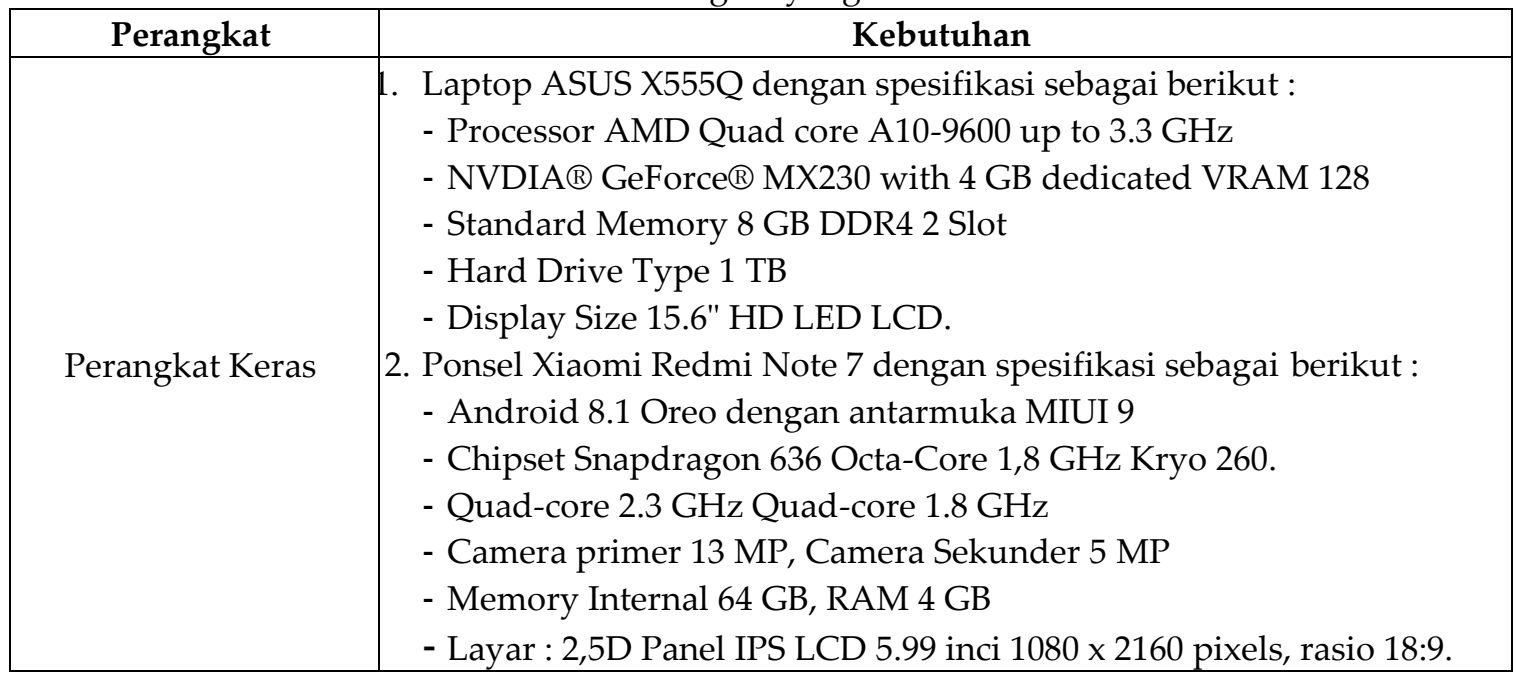




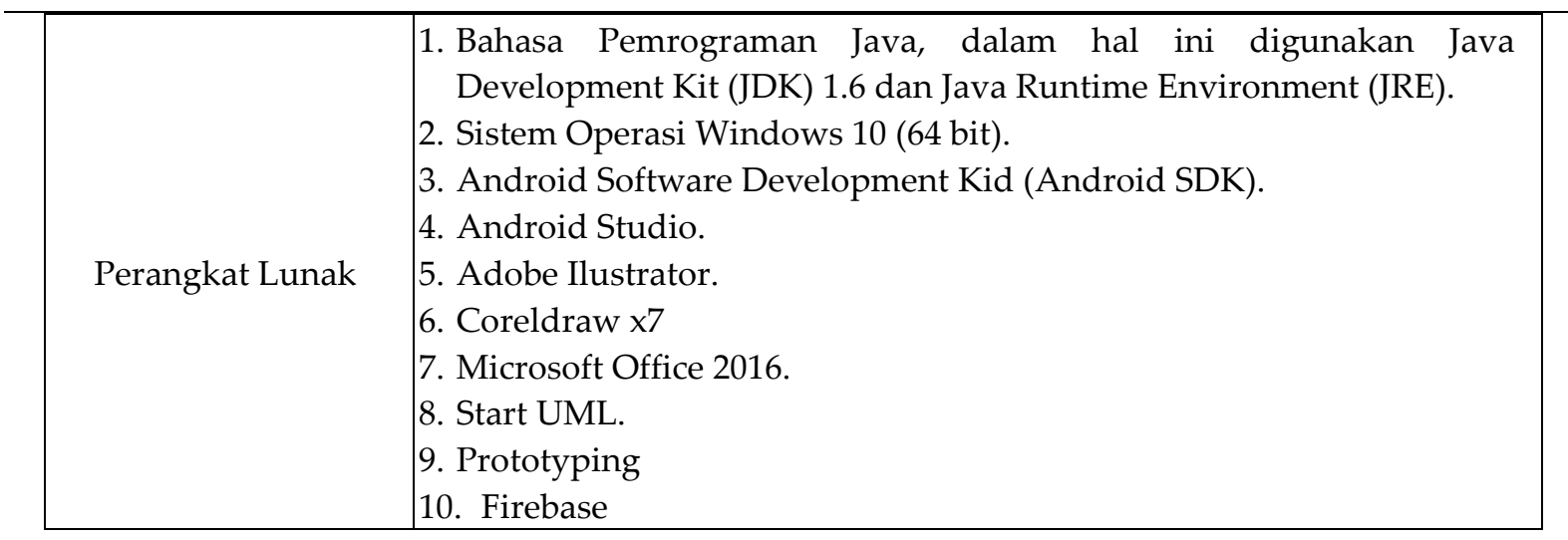

\section{Desain Aplikasi}

a. Bisnis Proses Admin Sumber Daya Mahasiswa (SDM)

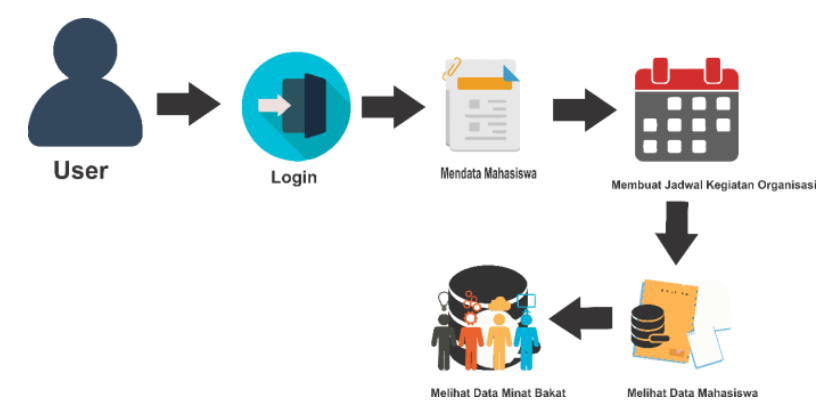

Gambar 2.2 Bisnis Proses Admin (SDM)

Sumber (Pengujian)

Keterangan pada Gambar 2.2 yaitu : user melakukan login untuk masuk ke page halaman login setalah melakukan login akan masuk ke page (SDM) pada page tersebut user meng-input data mahasiswa dan memilih menu untuk ke tampilan page berikutnya yaitu page membuat jadwal kegiatan organisasi, page selanjutnya untuk melihat data mahasiswa yang sudah tersimpan dan page terahir untuk melihat data minat bakat yang sudah di isi oleh mahasiswa.

b. Bisnis Proses Admin Sekretaris

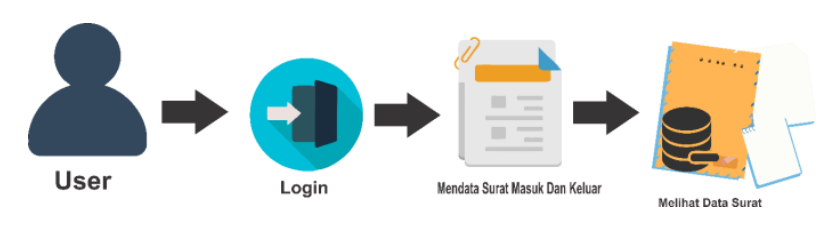

Gambar 2.3 Bisnis Proses Admin Sekretaris Sumber : Pengujian

Keterangan pada Gambar 2.3 yaitu : user sebelum masuk ke page login setelah melakukan login akan masuk ke page sekertaris dalam page tersebut user akan menginput data masuk surat dan data keluar surat serta buttom untuk melihat data surat, untuk tampilan berikutnya yaitu untuk tampilan data surat yang sudah tersimpan. 
c. Bisnis Proses Admin Bendahara

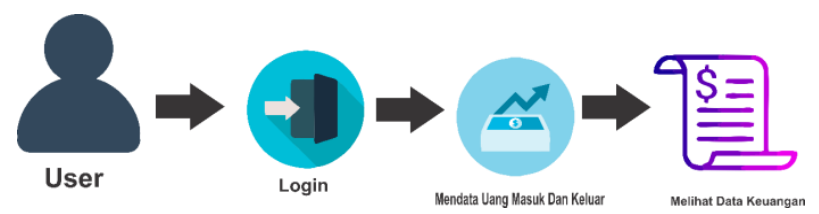

Gambar 2.4 Bisnis Proses Admin Bendahara

Sumber : Pengujian

Keterangan pada Gambar 2.4 yaitu : user melakukan login untuk masuk ke page halaman login setalah melakukan login akan masuk ke page bendahara, pada page tersebut untuk user meng-input data uang masuk dan data uang keluar serta buttom untuk melihat data keuangan, pada selanjutnya untuk melihat data keuangan yang tersimpan.

\section{Implimentasi Prototype}

Implementasi prototype adalah upaya untuk membuat aplikasi manajemen organisasi, pada proses ini yaitu membangun aplikasi dengan kode program java dengan menggunakan software Andoid Studio serta menggunakan data base dari gogle yaitu firebase.

\section{Proses ke User}

Proses ini adalah proses dimana aplikasi sudah menjadi desain dummy yang belum terkonekting dengan data base yang akan di bawakan ke user untuk penilaian desain aplikasi, apabila user telah menyetujui desain yang sudah benar tanpa adanya revisi produk maka akan di lanjutkan ke desain final.

\section{Desain Final (Desain GUI)}

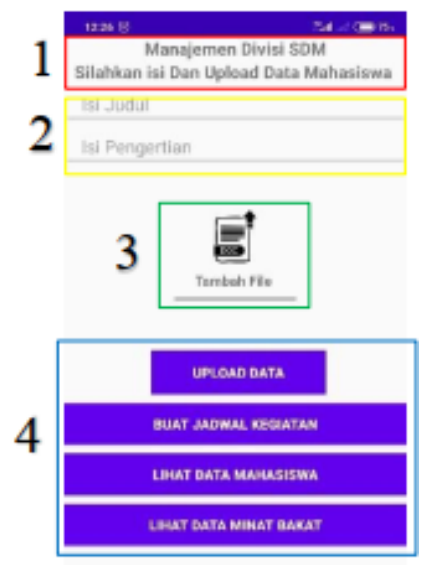

Gambar 2.5 Desain GUI Admin (SDM)

Sumber : Pengujian

Dari gambar di atas, keterangan untuk kolom No.1 menunjukan halaman, kolom No.2 untuk mengisi judul dan keterangan data mahasiswa, kolom No.3 untuk menambahkan file data mahasiswa, dan kolom No.4 button untuk upload dan masuk ke page tambah jadwal kegiatan, lihat data mahasiswa dan lihat data minat bakat. 


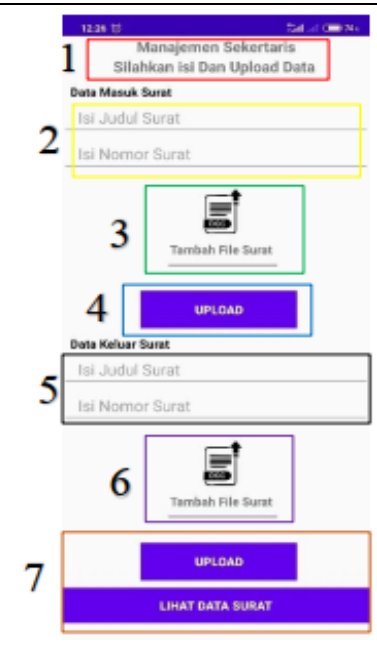

\section{Gambar 2.6 Desain GUI Admin Sekretaris}

Sumber : Pengujian

Dari gambar di atas keterangan untuk kolom No.1 menunjukan halaman, kolom No.2 untuk mengisi judul dan keterangan data surat masuk, kolom No.3 button untuk manambahkan file data surat masuk, kolom No.4 button untuk menyimpan data surat masuk, kolom No.5 untuk mengisi judul dan keterangan surat keluar, kolom No.6 untuk menambahkan file surat keluar, dan kolom untuk button menyimpan data surat keluar dan melihat data surat

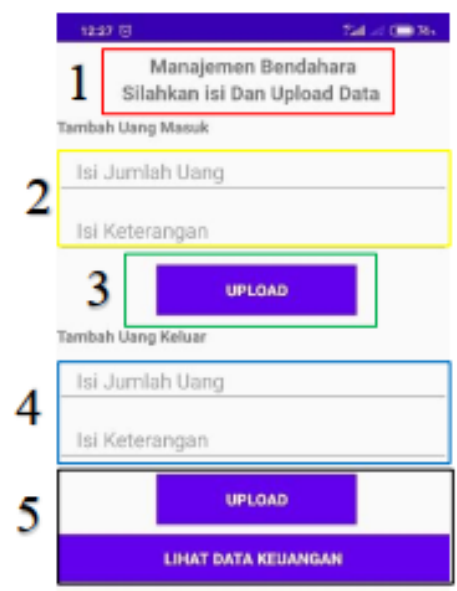

Gambar 2.7 Desain GUI Admin Bendahara

Sumber : Pengujian

Dari gambar di atas, keterangan untuk kolom No.1 menunjukan halaman, kolom No.2 untuk mengisi jumlah uang masuk dan keterangan, kolom No.3 button untuk menyimpan data uang masuk, kolom No.4 untuk mengisi jumlah uang keluar dan keterangan, kolom No.5 button untuk menyimpan data uang keluar dan melihat data keuangan. 


\section{Navigasi GUI}

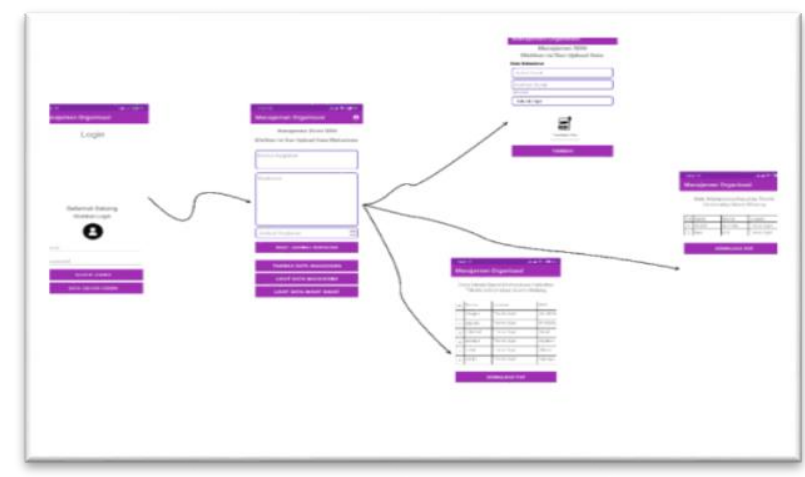

Gambar 2.8 Navigasi GUI Admin SDM

Sumber : Pengujian

Keterangan pada Gambar 2.8 tampilan navigasi GUI untuk admin sumberdaya mahasiswa dari mulai melakukan login apabila sudah berhasil akan ke tampilan (SDM) pada tampilan ini user bisa membuat jadwal kegiatan organisasi, membuat data mahasiwa, melihat data mahasiswa dan melihat data minat bakat mahasiswa.

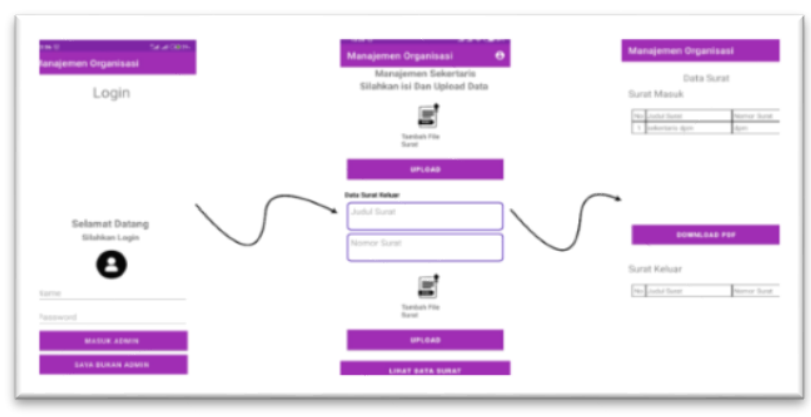

\section{Gambar 2.9 Navigasi GUI Admin Sekretaris}

Sumber : Pengujian

Keterangan pada Gambar 2.9 tampilan navigasi gui user melakukan login setelah melakukan login berhasil akan masuk ke page sekertaris dalam page tersebut user akan menginput data masuk surat dan data keluar surat serta buttom untuk melihat data surat, untuk tampilan berikutnya yaitu untuk tampilan data surat yang sudah tersimpan.

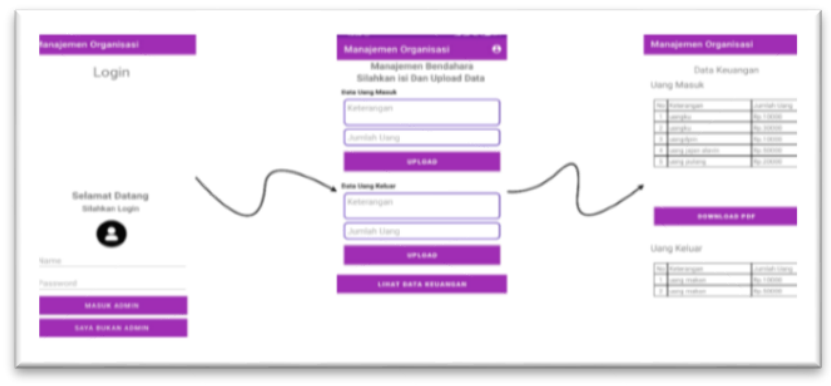

Gambar 2.10 Navigasi GUI Admin Bendahara

Sumber : Pengujian

Keterangan pada Gambar 2.10 tampilan navigasi gui user untuk login setalah melakukan login akan masuk ke page bendahara, pada page tersebut untuk user meng-input data uang masuk dan data uang keluar serta buttom untuk melihat data keuangan, pada selanjutnya untuk melihat data keuangan yang tersimpan. 


\section{Hasil and Pembahasan}

1. Interface Aplikasi

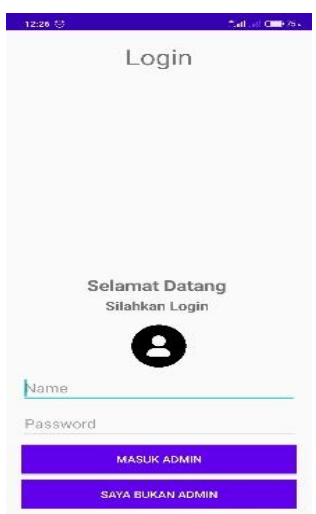

Gambar 3.1 Halaman Login

Sumber : Pengujian

Halaman pada Gambar 3.1 merupakan halaman utama setelah masuk aplikasi untuk melakukan login, pada halaman ini terdiri edit tekt untuk mengisi username dan password serta tombol masuk admin dan bukan admin.

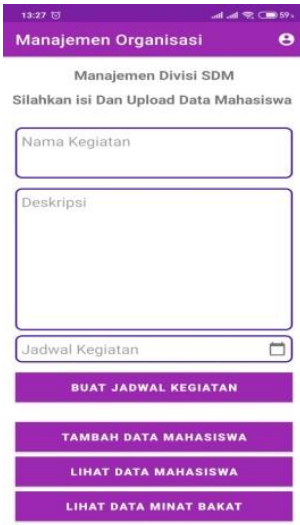

Gambar 3.2 Halaman Admin SDM

Sumber : Pengujian

Halaman pada Gambar 3.2 merupakan halaman lanjutan setelah masuk pada halaman (SDM) dam menekan tombol buat jadwal kegiatan, terdiri dari kalender untuk menandai tanggal, edit tekt untuk memberi keterangan dan save my date untuk menyimpan jadwal yang sudah di input. 


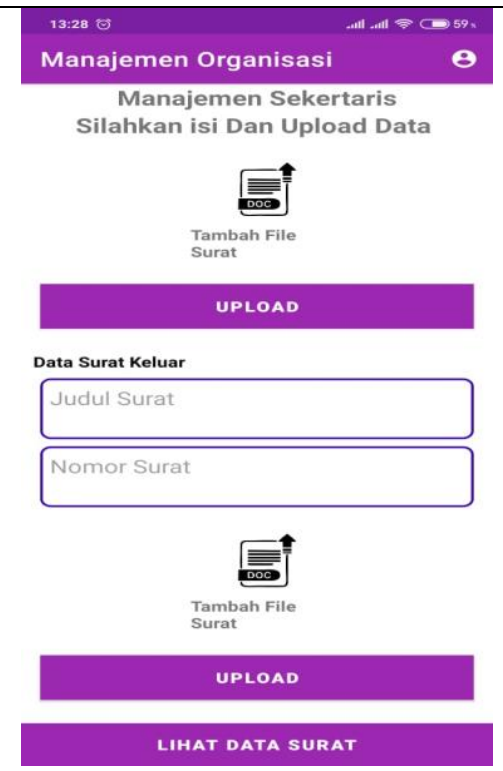

Gambar 3.3 Halaman Admin Sekretaris

Sumber : Pengujian

Halaman pada Gambar 3.3 merupakan halaman sekertaris setelah melakukan login, terdiri dari edit tekt untuk memberi keterangan input surat masuk dan keluar, tombol upload untuk menyimpan data surat yang sudah di input dan tombol lihat data surat.

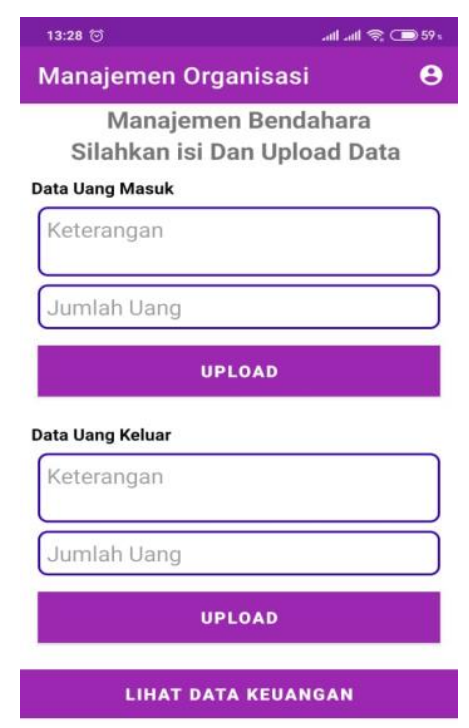

Gambar 3.4 Halaman Admin Bendahara

Sumber : Pengujian

Halaman pada Gambar 3.4 merupakan halaman bendahara setelah berhasil login, terdiri dari edit tekt untuk memberi keterangan uang masuk dan uang keluar, tombol upload untuk menyimpan data uang yang sudah di input dan lihat data keuangan.

\section{Tahap Pengujian Fitur}

Untuk memberi isi keterangan di bawah ini yaitu dengan tanda checklist $(\sqrt{ })$. Keterangan isi tabel berikut ini Sangat Baik, Baik, Cukup Baik, Kurang, Sangat Kurang, untuk penilaian fitur pada "Aplikasi Manajemen Organisasi Fakultas Teknik Universitas Islam Malang."

a. Fitur Admin SDM

Tabel 3.1 Hasil Pengujian Fitur Admin SDM 


\begin{tabular}{|l|l|c|c|c|c|c|}
\hline No & \multicolumn{1}{|c|}{ Nama Fitur } & SB & B & CB & K & SK \\
\hline 1. & Upload Data & & $\sqrt{ }$ & & & \\
\hline 2. & Buat Jadwal Kegiatan & & & $\sqrt{ }$ & & \\
\hline 3. & Lihat Data Mahasiswa & & $\sqrt{ }$ & & & \\
\hline 4. & Lihat Data Minat Bakat & & $\sqrt{ }$ & & & \\
\hline 5. & Save My Date & & $\sqrt{ }$ & & & \\
\hline
\end{tabular}

b. Fitur Admin Sekretaris

Tabel 3.2 Hasil Pengujian Fitur Admin Sekretaris

\begin{tabular}{|l|l|l|l|l|l|l|}
\hline No & Nama Fitur & SB & B & CB & K & SK \\
\hline 1. & Input Keterangan Surat & & & $\sqrt{ }$ & & \\
\hline 2. & Input File Surat & & & $\sqrt{ }$ & & \\
\hline 3. & Upload Surat Masuk & & $\sqrt{ }$ & & & \\
\hline 4. & Upload Surat Keluar & & $\sqrt{ }$ & & & \\
\hline 5. & Lihat Data Surat & & $\sqrt{ }$ & & & \\
\hline
\end{tabular}

Fitur Admin Bendahara

\begin{tabular}{|l|l|l|l|l|l|l|}
\hline No & Nama Fitur & SB & B & CB & K & SK \\
\hline 1. & Input Keterangan & & & $\sqrt{ }$ & & \\
\hline 2. & Upload Uang Masuk & & & $\sqrt{ }$ & & \\
\hline 3. & Upload Uang Keluar & & $\sqrt{ }$ & & & \\
\hline 4. & Lihat Data Keuangan & & $\sqrt{ }$ & & & \\
\hline
\end{tabular}

c. Kelayakan Pengujian Pengguna

\begin{tabular}{|r|l|l|}
\hline No & Penilaian & Jumlah skor \\
\hline 1. & Sangat Kurang & 0 \\
\hline 2. & Kurang & 0 \\
\hline 3. & Cukup Baik & 3 \\
\hline 4. & Baik & 152 \\
\hline 5. & Sangat Baik & 55 \\
\hline Jumlah & 210 \\
\hline
\end{tabular}

Skor total $(X) \quad=210$

Jumlah butir kriteria $\quad=5$

Skor tertinggi ideal = Jumlah butir kriteria $\mathrm{x}$ responden $\mathrm{x}$ skor tertinggi

$=5 \times 10 \times 5$

$=250$

Skor terendah ideal $=$ Jumlah butir kriteria $\mathrm{x}$ responden $\mathrm{x}$ skor terendah

$=5 \times 10 \times 1$

$=50$

Mi

$=(1 / 2) \times($ skor tertinggi ideal + skor terendah ideal $)$

$=(1 / 2) \times(250+50)$

$=150$

SBI

$=(1 / 3) \times(1 / 2) \times($ skor tertinggi ideal - skor terendah ideal $)$

$=(1 / 3) \times(1 / 2) \times(250-50)$

$=33,34$ 


\begin{tabular}{|c|c|c|}
\hline No & Rentang Skor & Kategori \\
\hline 1 & $\begin{array}{l}\mathrm{Mi}+(1,80 \times 33,34)<\mathrm{X} \\
60,012<\mathrm{X}\end{array}$ & Sangat Layak \\
\hline 2 & $\begin{array}{l}\mathrm{Mi}+(0,6 \times 33,34)<\mathrm{X} \leq \mathrm{Mi}+(1,80 \times 33,34) \\
\mathbf{2 0 , 0 0 4}<\mathrm{X} \leq 60,12\end{array}$ & Layak \\
\hline 3 & $\begin{array}{l}\mathrm{Mi}-(0,6 \times 33,34)<\mathrm{X} \leq \mathrm{Mi}+(0,6 \times \\
33,34) \\
20,004<\mathrm{X} \leq 20,004\end{array}$ & Cukup Layak \\
\hline
\end{tabular}

Presentase Kelayakan $=\frac{\text { Skor Hasil Observasi }}{\text { Skor yang Diharapkan }} \times 100$

$$
\begin{gathered}
=\frac{210}{250} \times 100 \% \\
=84 \%
\end{gathered}
$$

d. Kelayakan Pengujian Black Box Fitur

\begin{tabular}{|r|l|l|l|}
\hline No & Penilaian & $\begin{array}{l}\text { Jumlah Hasil } \\
\text { kriteria }\end{array}$ & Jumlah skor \\
\hline 1. & Ya & 0 & 0 \\
\hline 2. & Tidak & 7 & 700 \\
\hline Jumlah & & 700 \\
\hline
\end{tabular}

Skor total $(X) \quad=700$

Jumlah butir kriteria $\quad=7$

Skor tertinggi ideal = Jumlah butir kriteria $\mathrm{x}$ responden $\mathrm{x}$ skor tertinggi

$=7 \times 1 \times 100$

$=700$

Skor terendah ideal $=$ Jumlah butir kriteria $\mathrm{x}$ responden $\mathrm{x}$ skor terendah

$=7 \times 1 \times 50$

$=350$

Mi

$=(1 / 2) \times($ skor tertinggi ideal + skor terendah ideal $)$

$=(1 / 2) \times(700+350)$

$=1.050$

SBI

$=(1 / 3) \times(1 / 2) \times($ skor tertinggi ideal - skor terendah ideal $)$

$=(1 / 3) \times(1 / 2) \times(700-350)$

$=52,5$

\begin{tabular}{|l|l|c|}
\hline No & Rentang Skor & Kategori \\
\hline 1 & $\begin{array}{l}\text { Mi }+(1,80 \times 52,5)<\mathrm{X} \\
94,5<\mathrm{X}\end{array}$ & Sangat Layak \\
\hline 2 & $\mathrm{Mi}+(0,6 \times 52,5)<\mathrm{X} \leq \mathrm{Mi}+(1,80 \times 52,5)$ & Layak \\
& $31,32<\mathrm{X} \leq 94.5$ & Cukup Layak \\
\hline 3 & $\mathrm{Mi}-(0,6 \times 52,5)<\mathrm{X} \leq \mathrm{Mi}+(0,6 \mathrm{x}$ & \\
& $52,5)$ & \\
\hline
\end{tabular}




$$
\begin{gathered}
\text { Presentase Kelayakan }=\frac{\text { Skor Hasil Observasi }}{\text { Skor yang Diharapkan }} \times 100 \\
=\frac{700}{700} \times 100 \% \\
=100 \% \text { Sangat layak }
\end{gathered}
$$

\section{Kesimpulan}

Berdasarkan hasil penelitian dan pembahasan, dapat disimpulkan sebagai berikut :

1. Dengan merealisasikan pembuatan aplikasi Manajemen Organisasi sebagai media untuk manajemen organisasi di Fakultas Teknik Universitas Islam Malang dilakukan dengan beberapa tahap yaitu analisis (analisis kebutuhan, analisis hardware, dan analisis software), desain (desain sistem dan desain interface), pengembangan (perancangan desain interface dan pembuatan program), implementasi (uji media dan uji pengguna), dan evaluasi (kualitas perangkat lunak, kelebihan, kekurangan, dan rekomendasi media yang dikembangkan). Aplikasi Manajemen Organisasi dibuat dengan software Android Studio yang merupakan software untuk membuat aplikasi android. Dengan adanya aplikasi tersebut, aplikasi yang dibangun yaitu "Manajemen Organisasi" memenuhi permintaan dari objek penelitian.

2. Sistem yang dapat membantu memanajemen organisasi dalam aplikasi ini yaitu untuk manajemen departemen organisasi antara lain departemen sumber daya mahasiswa (SDM), departemen Sekertaris, Departemen Bendahara, Departemen Kerumahtanggaan (KRT) dan departemen Media dan Informasi (MEDINFO).

3. Hasil pengujian kualitas aplikasi Manajemen Organisasi meliputi pengujian pengguna dan fitur, salah satu untuk bentuk tolak ukur ke akuratan aplikasi "Manajemen Organisasi Mahasiswa" hasil pengujian aplikasi, hasil uji ke pengguna organisasi mahasiswa fakultas teknik dikategorikan sangat layak dengan persentase kelayakan sebesar $84 \%$. Dan hasil pengujian fitur aplikasi di kategorikan sangat layak dengan presentase kelayakan 100\%. Dengan demikian aplikasi Manajemen organisasi Mahasiswa dapat dikatakan sangat layak untuk menjadi media untuk manajemen organisasi.

\section{SARAN}

Pengembangan aplikasi Manajemen Organisasi Mahasiswa masih terdapat beberapa kekurangan, sehingga terdapat beberapa saran untuk mengembangan ke depan yaitu antara lain:

1. Bagi pengembang

a. Aplikasi Manajemen Organisasi Mahasiswa dapat di kembangakan untuk menampilkan suatu berita dan pengertian organisasi ke situs WEB karena untuk mempermudah pengguna dalam mengunjungi ataupun melihat suatu berita.

b. Dapat di kembangkan aplikasi dengan menambahkan beberapa fitur yang akan di butuhkan setiap organisasi terkait.

c. Sehingga dapat dikembangkan dengan menambahkan user admin untuk seluruh organisasi mahasiswa yang ada di Universitas Islam Malang.

d. Aplikasi Manajemen Organisasi Mahasiswa dapat dikembangkan dalam bentuk mobile multiplatform server

\section{Refrensi}

[1] Rifa'i dan Fadhli, Manajemen Organisasi, vol. 53, no. 9. 2013.

[2] R. Bangun and A. Pembelajaran, "Rancang Bangun Aplikasi Pembelajaran Hadis Untuk Perangkat Mobile Berbasis Android," J. Inform., vol. 8, no. 2, pp. 907-920, 2014, doi: 10.26555/jifo.v8i2.a2057.

[3] A. J. Oktasari and D. Kurniadi, “Perancangan Sistem Informasi Manajemen Kegiatan Mahasiswa Berbasis Web," J. Vokasional Tek. Elektron. dan Inform., vol. 7, no. 4, pp. 150-157, 2019.

[4] E. Danu, R. R. Astanti, J. T. Informatika, U. C. Diagram, and A. Diagram, “Rancang Bangun 
Aplikasi Sistem Informasi Pada Badan Eksekutif Mahasiswa STMIK Pontianak," pp. 234-245.

[5] S. L. Apriliani, S. Esabella, M. Julkarnain, P. S. Informatika, F. Teknik, and U. T. Sumbawa, "Rancang Bangun Aplikasi Monitoring Unit Kegiatan Mahasiswa (Ukm) Universitas Teknologi Sumbawa Berbasis Web," J. Tek. Sains, vol. 1, no. 2, pp. 18-22, 2020.

[6] S. Wulandari, "Rancang Bangun Sistem Informasi Budgeting Ormawa Universitas Muhammadiyah Semarang Berbasis Web," J. Unimus Media Elektr., vol. 13, no. 1, pp. 43-53, 2020.

[7] F. Nugraha, M. Arifin, and A. Harjanto, "Rancang Bangun Sistem Informasi Manajemen Proposal Kemahasiswaan," J. Sist. Inf. Manaj. Basis Data, vol. 03, no. 01, pp. 51-59, 2020.

[8] J. Ario Yustin, H. sujaini, and M. Azhar Irwansyah, "Rancang Bangun Aplikasi Game Edukasi Pembelajaran Matematika Menggunakan Construct 2," J. Sist. dan Teknol. Inf., vol. 1, no. 1, pp. 422-426, 2016, [Online]. Available: https://jurnal.untan.ac.id/index.php/justin/article/view/16354.

[9] N. Sopiah, F. Ilmu, K. Universitas, and B. Darma, "Penggunaan metode analisis dan rancangan berorientasi objek pada web jurnal ilmiah terpadu,". 